\title{
TRANSFUSION OF NEOCYTES CONCENTRATE/POOLED NEOCYTES AND CONVENTIONAL PACKED RED BLOOD CELLS IN BETA-THALASSEMIA MAJOR PATIENTS: A COMPARATIVE STUDY
}

\author{
Dharmakanta Kumbhakar ${ }^{1}$
}

${ }^{1}$ Associate Professor, Department of Pathology, Tezpur Medical College and Hospital, Tezpur, Assam.

\section{ABSTRACT}

\section{BACKGROUND}

Beta-thalassemia major patients require continuous red blood cells transfusion therapy for maintaining their haemoglobin level between 10-12 gm/dL and survive. Each unit of red blood cells (About $180 \mathrm{ml}$ ) transfusion adds chances of transfusion related hazards and adds about 200-250 mg of extra irons to the recipients. Previous studies of neocytes concentrate/pooled neocytes transfusion demonstrated decreased numbers of required red blood cells transfusion by extending transfusion intervals, decreased incidences of transfusion related hazards and reduction of iron overload in these patients.

\section{AIMS AND OBJECTIVES}

To compare the results of neocytes concentrate/pooled neocytes transfusion over conventional packed red blood cells transfusion in a group of beta-thalassemia major patients to maintain normal physiological level of haematocrit ( $\geq 35 \%$ ) and haemoglobin level ( $\geq 11 \mathrm{gm} / \mathrm{dL}$ ) as per super-transfusion regimen and with previous studies.

\section{MATERIALS AND METHODS}

For the study, we selected twelve (12) transfusion-dependant beta-thalassemia major patients of age group 3-10 years to maintain haematocrit $(\geq 35 \%)$ and haemoglobin level $(\geq 11 \mathrm{gm} / \mathrm{dL})$ as per super-transfusion regimen for nine (09) months (172 days) period from June 11, 2010 to March 8, 2011 at Gauhati Medical College and Hospital, Guwahati. Six (06) beta-thalassemia major patients were transfused with conventional packed red blood cells (Control group) and remaining six (06) beta-thalassemia major patients were transfused with neocytes concentrate/pooled neocytes (Study group). Product volumes were calculated as per body weight of the child (15 millilitre red blood cells per kg body weight), who were under iron chelating therapy before and during the study period. Neocytes concentrate were prepared by centrifugation and separation method from fresh whole blood by recovering top 50-60 percent volume of packed red blood cells and pooling were done as per calculation.

\section{RESULTS AND OBSERVATIONS}

After the study period, percentage of decreased numbers of required transfusion in the study group was $41.67 \%$ than the control group. The transfusion interval observed in the study group was 41-48 days (Average 45 days) and in the control group it was 2127 days (average 24.5 days). Patient serum iron reduction was observed $41.67 \%$ in study group in comparison to control group.

\section{CONCLUSION}

Transfusion of neocytes concentrate/pooled neocytes leads beta-thalassemia major patients a better quality of life expectancy than conventional packed red blood cells transfusion correcting anaemia, decreasing required numbers of red blood cells transfusion by extending transfusion intervals, reducing incidences of transfusion related hazards, helping in proper growth and bone development by reducing in the rate of ineffective erythropoiesis and reducing iron overload with related complications.

\section{KEYWORDS}

Beta-Thalassemia, RBC, Iron, Haemoglobin, Haematocrit, Transfusion, Neocytes, Gerocytes, Siderosis, Neocytapheresis, Overload, Erythropoiesis, Homozygous, Inheritance.

HOW TO CITE THIS ARTICLE: Kumbhakar D. Transfusion of neocytes concentrate/pooled neocytes and conventional packed red blood cells in beta-thalassemia major patients: a comparative study. J. Evolution Med. Dent. Sci. 2016;5(61):4285-4290, DOI: $10.14260 /$ jemds/2016/978

INTRODUCTION
Beta-thalassemia is an autosomal recessive genetic disorder, which is widespread throughout the Mediterranean region, Africa, the Middle East, the Indian subcontinent and South East Asia.[1]

Financial or Other, Competing Interest: None.

Submission 15-06-2016, Peer Review 20-07-2016,

Acceptance 25-07-2016, Published 01-08-2016.

Corresponding Author:

Dr. Dharmakanta Kumbhakar,

Associate Professor,

Department of Pathology,

Tezpur Medical College and Hospital,

Tezpur, Sonitpur,

Assam.

E-mail: drkdharmakanta@yahoo.com

DOI: $10.14260 /$ jemds $/ 2016 / 978$
Homozygous inheritance of a genetic defect results in the inability of the beta-thalassemia major patients to manufacture beta-globin chains essential for the production of normal adult haemoglobin. Consequently, insufficient haemoglobin is produced and severe anaemia occurs in the early life of these patients. [2] Beta-thalassemia major, which is clinically the most severe form and the affected children are dependent on regular red blood cells transfusion for survival.[3]

Patients with beta-thalassemia major require repeated red blood cells transfusion therapy in order to maintain their haemoglobin level between 10-12 gm/dL and survive.[4] Repeated red blood cells transfusion ensures an active life, adequate growth, proper bone development and prevents ill effects of chronic anaemia. Unless treated, the survival time 
of beta-thalassemia major patients are short, only few years. [5]

Chronic transfusion therapy increases the lifespan of beta-thalassemia major patients considerably correcting the anaemia[6] and maintaining the circulating level of haemoglobin $(\mathrm{Hb})$ sufficient to suppress endogenous ineffective erythropoiesis.[7,8]

The current management of beta-thalassemia major patient is based on regular transfusion of conventional packed red blood cells and effective chelating therapy.[9,10] Currently, we follow several transfusion regimens to maintain the required haemoglobin level in the patients for treatment of beta-thalassemia major patients. In hypertransfusion regimen, the pre-transfusion haemoglobin level is maintained as $\geq 10 \mathrm{gm} / \mathrm{dL}$ with mean haemoglobin level of about $12 \mathrm{gm} / \mathrm{dL}$, immediate post-transfusion haemoglobin level rising to $14 \mathrm{gm} / \mathrm{dL}$ and returning to baseline after 3-4 weeks. In the super-transfusion regimen, the pre-transfusion haemoglobin level is maintained at $\geq 11$ $\mathrm{gm} / \mathrm{dL}$ or a haematocrit of $\geq 35 \%$ with a mean haemoglobin level of about $14 \mathrm{gm} / \mathrm{dL}$, while in moderate transfusion regimen the pre-transfusion haemoglobin level is maintained at the values between 9 and $10 \mathrm{gm} / \mathrm{dL}$. Generally, conventional packed red blood cells are transfused (10-15 $\mathrm{mL}$ per kg body weight) by hypertransfusion regimen in our country. This treatment however increases the incidences of transfusion related hazards.[11]

As in chronic transfusion therapy red blood cells are transfused, so there are chances of transfusion reactions such as fever, allergy and transfusion related lung injury, etc. To reduce the incidences of transfusion reactions in chronic transfusion therapy patients, we should perform indirect anti-globulin cross matching.[12] Other transfusion products that can be used are leuco-depleted red blood cells, leucoreduced red blood cells and saline washed red blood cells to reduce the transfusion reactions. Though nowadays enzymelinked immunosorbent tests are mandatory for screening of Hepatitis B virus, Hepatitis C virus, Human immunodeficiency virus in donated blood as per National Aids Control Society guidelines; till there are chances of transfusion transmission of these infections due to window period. To reduce this we should transfuse red blood cells of known regular voluntary blood donors with no risk behaviours. Moreover, as in India we do not screen donated blood for other transfusion transmitted infectious agents, so there are chances of transfusion transmitted infections such as Hepatitis G virus, Cytomegalovirus, Kaposi's sarcoma and human herpes virus-8, Babesiosis, Leishmaniasis, Toxoplasmosis, Chagas disease, Cryoglobulinemia and bacterial infections.

Major complications in chronically transfused patients are due to iron overload.[13] So this treatment may also produce its own characteristic pathology: Siderosis. Each millilitre of red blood cells contains about $1 \mathrm{mg}$ of iron. The added extra irons to the beta-thalassemia major patients from the transfused red blood cells cannot be excreted quickly and efficiently. These extra irons may cause iron overload (Haemosiderosis) in these patients getting regular red blood cells transfusion. Traditional therapy for this complication is iron chelating-agents that enhance the urinary excretion of irons.[14,15] Later these irons may be deposited in different tissues/organs of the patients getting red blood cells transfusions, usually more than 100 units of conventional packed red blood cells transfusions and produce siderosis and its sequel: growth failure, hypogonadism, diabetes mellitus, hepatic disease, cardiac failure and death.

Neocytes transfusion may be useful in the treatment of young patients with severe chronic anaemia (e.g. betathalassemia major patients) or adult with severe chronic anaemia (Chronic kidney disease) who require repeated red blood cells transfusion and are expected to have a prolonged survival (Propper et al 1980).[16] The main goal of neocytes transfusion is reduction of numbers of required transfusion by extending the transfusion intervals to prevent incidence of transfusion related hazards and iron overload (Haemosiderosis) and its sequel: growth failure, hypogonadism, diabetes mellitus, hepatic disease, cardiac failure and death.[17,18]

Usually, we prefer conventional packed red blood cells transfusion to beta-thalassemia major patients as chronic transfusion therapy. But, previous studies show that transfusion of concentrated neocytes/pooled neocytes demonstrated reduction in numbers of required transfusion, extension of transfusion intervals, reduction of the incidences of transfusion related hazards and reduction of iron overload in patients with beta-thalassemia major.[19,20] The programme of super-transfusion of neocytes produces a significant decrease in the rate of iron accumulation in patients with beta-thalassemia major. The conventional packed red blood cells contain both neocytes and gerocytes ranging age from 1 day old to 120 days old. The gerocytes are old red blood cells having short life span, which live few days in the transfusion recipients. The neocytes are young red blood cells having long lifespan, which live more days in the transfusion recipients. The concept of transfusion of younger red blood cells, i.e. neocytes was introduced by Propper in 1980 in beta-thalassemia major patients. If neocytes with an average 90 days lifespan are transfused instead of conventional packed red blood cells with an average 60 days lifespan (Half-life of neocyte is almost twice that of conventional red blood cell) to a beta-thalassemia major patient, then the time interval between two transfusions can be increased, incidences of transfusion related hazards and the chances of inducing haemosiderosis may be reduced by decreasing numbers of required red blood cells units transfusion as neocytes survive in the circulation longer than older cells and may reduce the total red blood cells requirement.[21] The inconvenience of pooled neocytes transfusion is exposure to a large number of donors.

Various techniques have been developed to collect neocytes. One approach is in the form of aphaeresis termed as neocytaphaeresis.[22] We can prepare concentrated neocytes by centrifugation and separation technique using refrigerated centrifuge by the principle of density. This method involves the selective removal of top 50-60\% volume of packed red blood cells of voluntary donor's fresh blood (within 6 hours of collection) taking into account that younger cells are larger and more buoyant than the smaller and more dense older cells. In USA Pat. 4416:778 to Rogers, a modified system of connected blood container is used for neocytes preparation. IIere filter is used to prevent white blood cells contamination. EPO application no. 0,191,360 is an elongated double bag 
system with a funnel shaped exit to separate neocytes in a satellite bag of length and width ratio 2.5:1.

\section{AIMS AND OBJECTIVES}

To compare the results of neocytes concentrate/pooled neocytes transfusion over conventional packed red blood cells transfusion in a group of beta-thalassemia major patients to maintain normal physiological level of haematocrit ( $\geq 35 \%$ ) and haemoglobin level ( $\geq 11 \mathrm{gm} / \mathrm{dL}$ ) as per super-transfusion regimen and with previous studies.

\section{MATERIALS AND METHODS}

Twelve (12) cases of transfusion dependant beta-thalassemia major were selected for the study between age group of 3-10 years in Gauhati Medical College and Hospital, Guwahati, to maintain normal physiological level of haematocrit $(\geq 35 \%$ ) and haemoglobin level ( $\geq 11 \mathrm{gm} / \mathrm{dL}$ ) as per super-transfusion regimen. The beta-thalassemia major patients were asked to come for red blood cells transfusion when they feel weakness. The transfusion intervals were determined on the level of haematocrit and haemoglobin level of the patients as stated above. Tests done on the patients' blood were haemoglobin estimation, haematocrit estimation, complete blood count, RBC indices by automatic electronic cell counter collecting blood in EDTA vials and peripheral smear study and reticulocyte count by conventional methods before red blood cells transfusion. On the tests, if we found the haematocrit value is lesser than $35 \%$ or the haemoglobin level is lesser than $11 \mathrm{gm} / \mathrm{dL}$ of the cases, they were put for red blood cells transfusion.

Volume of single transfusion was in between 120 to 300 millilitre of red blood cells using a calculation of 15 millilitre red blood cells per kg body weight of the child. All the patients were under iron chelating therapy (Deferoxamine 50-75 mg per kg body weight per day) before and during the study period. Six (06) patients were transfused with conventional packed red blood cells (Control group) and remaining six (06) patients were transfused with neocytes concentration/pooled neocytes (Study group) for nine (09) months (172 days) from June 11, 2010 to March 8, 2011.

All the units for transfusion whether neocytes concentrate or conventional packed red blood cells were prepared from fresh whole blood collected (within 6 hours of collection) from criteria fulfilled known repeated voluntary blood donors with no risk behaviour for safe blood transfusion and to reduce the risk of transmission of transfusion Human Immunodeficiency Virus, Hepatitis B Virus and Hepatitis C Virus during window period.[23]

Neocytes concentrations were prepared by centrifugation and separation technique with a refrigerated centrifuge named Cryofuge 6000-i maintaining requisite quality control. The machine was calibrated well regularly by service engineer. Pooling of neocytes concentrate was done as per volume requirement for transfusion to the patient, as per calculation in the state of the art model blood bank, Gauhati Medical College and Hospital, Guwahati. We used closed system using quadra and triple free blood bags, where bags were attached to each other by tubing and valving. The donor bag contained $49 \mathrm{~mL}$ of anti-coagulant Citrate Phosphate Dextrose Adenine (CPDA) and satellite bags were free; 350 $\mathrm{mL}$ of whole blood was collected from known repeated voluntary blood donors after proper screening and medical examination. After balancing the collected anti-coagulant mixed fresh whole blood, the entire triple system was put in a centrifuge cup and centrifuged according to required centrifugal force, temperature and time to form the upper lighter plasma portion and lower heavy concentrated red blood cells portion.

The concentrated red blood cells portion was conventional packed red blood cells, which contains both neocytes and gerocytes were transfused to the control group patients. After opening a valve in the system, we expressed the upper plasma portion into one free satellite bag. We used the plasma to prepare Platelet Rich Plasma (PRP), Platelet Concentration, Cryo-precipitate, Fresh Frozen Plasma (FFP), Factor VIII Concentrate, etc. From the separated concentrated red blood cells, we recovered the top 50-60\% volume, which was concentrated neocytes. The remaining bottom portion was concentrated gerocytes. Pooling of neocytes concentrate was done by sterile tube connecting system device according to requirement of the patient and stored at 04 degree centigrade and transfused later accordingly.

After proper testing both neocytes concentrate and conventional packed red blood cells were cross matched with the recipients by indirect anti-globulin cross matching technique at the blood bank of Gauhati Medical College and Hospital, Guwahati, to reduce the risk of transfusion reactions.[24] $\mathrm{ABO}$ and $\mathrm{Rh}-\mathrm{D}$ group specific products were transfused to both study and control group in thalassemia unit of Gauhati Medical College and Hospital, Guwahati under medical supervision. Appropriate quality control was maintained in the blood bank. Care was taken during pre-, intra- and post-transfusion of the products to the patients. All aspect of the study and entries of records were double checked by the author.

\section{RESULTS AND OBSERVATIONS}

During the study period of 09 months (172 days) from June 11, 2010 to March 8, 2011 at Gauhati Medical College and Hospital, Guwahati, the numbers of required transfusion for both study group and control group, differences in numbers of transfusion between two groups, time intervals in days between two transfusions with average were recorded for both study group and control group.

\begin{tabular}{|c|c|c|}
\hline $\begin{array}{c}\text { Numbers of } \\
\text { Neocytes } \\
\text { Concentrate/ } \\
\text { Pooled Neocytes } \\
\text { Required in Study } \\
\text { Group }\end{array}$ & $\begin{array}{c}\text { Numbers of } \\
\text { Conve- } \\
\text { ntional } \\
\text { Packed } \\
\text { RBCs } \\
\text { Required in } \\
\text { Control } \\
\text { Group }\end{array}$ & $\begin{array}{l}\text { Difference of } \\
\text { Numbers of } \\
\text { Units Required } \\
\text { in Control and } \\
\text { Study Group }\end{array}$ \\
\hline 07 & 12 & 05 \\
\hline
\end{tabular}

Table 1 shows that the study group patient required seven (07) units of neocytes concentrate/pooled neocytes transfusion, whereas the control group patient required twelve (12) units of conventional packed red blood cells. Hence, we see that five (05) numbers of lesser units were required for the study group than control group for transfusion in the study period. The percentage of decreased required numbers of transfusion in the study group is $(5 / 12$ 
$X 100) 41.67 \%$ than the required numbers of transfusion in the control group.

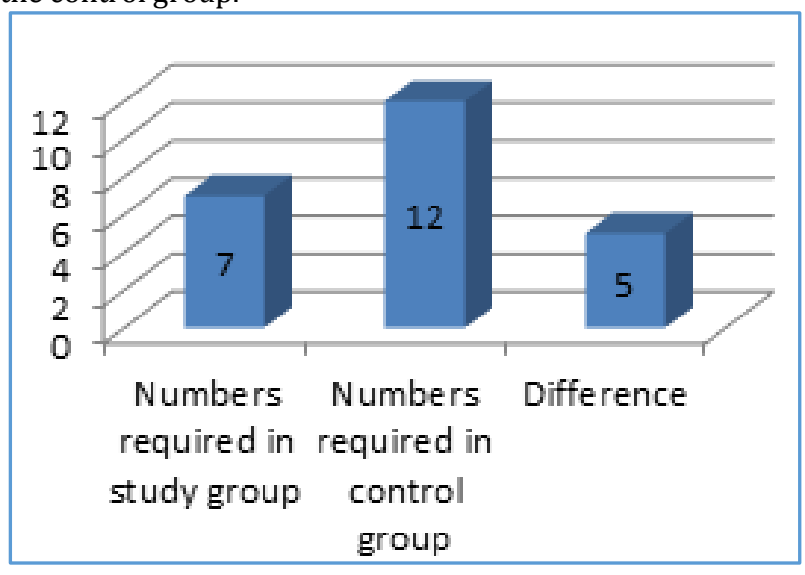

Fig. 1: Numbers of Product Required and Difference in Study Group and Control Group

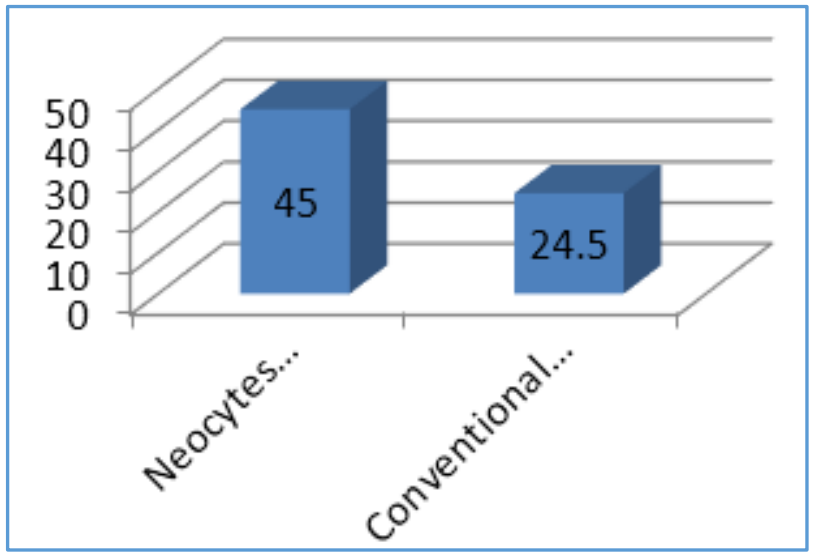

Fig. 2: Average Transfusion Intervals in Days in Transfusion of NCTT and CRTT

\begin{tabular}{|c|c|c|c|c|c|c|c|}
\hline Patient I.D. No. & $\mathbf{1}^{\text {st }} \boldsymbol{\text { 2nd }}$ & $\mathbf{2}^{\text {nd }} \boldsymbol{\&}$ 3rd & $\mathbf{3}^{\text {rd }} \boldsymbol{\text { 4th }}$ & $\mathbf{4}^{\text {th }} \boldsymbol{\text { 5 5th }}$ & $\mathbf{5}^{\text {th }} \boldsymbol{\text { 6 6th }}$ & $\mathbf{6}^{\text {th }}$ \& 7th & Average \\
\hline NCTT-1 & 42 & 44 & 46 & 41 & 48 & 43 & 44 \\
\hline NCTT-2 & 47 & 45 & 47 & 46 & 45 & 46 & 46 \\
\hline NCTT-3 & 45 & 48 & 47 & 48 & 46 & 48 & 47 \\
\hline NCTT-4 & 43 & 45 & 46 & 42 & 43 & 45 & 44 \\
\hline NCTT-5 & 47 & 44 & 47 & 46 & 47 & 45 & 46 \\
\hline NCTT-6 & 45 & 42 & 44 & 42 & 43 & 42 & 43 \\
\hline Average & 44.83 & 44.67 & 46.17 & 44.17 & 45.33 & 44.83 & 45 \\
\hline
\end{tabular}

\begin{tabular}{|c|c|c|c|c|c|c|c|c|c|c|c|c|}
\hline $\begin{array}{l}\text { Patient } \\
\text { I.D. No }\end{array}$ & $\begin{array}{l}\text { 1st \& } \\
\text { 2nd }\end{array}$ & $\begin{array}{c}\text { 2nd } \&^{\text {nd }} \\
\text { 3rd }\end{array}$ & $\begin{array}{c}\text { 3rd \& } \\
4 \text { th }\end{array}$ & $\begin{array}{l}4^{\text {th }} \& \\
5 \text { th }\end{array}$ & $\begin{array}{c}5^{\text {th }} \& \\
6^{6 \text { th }}\end{array}$ & $\begin{array}{c}6^{\text {th }} \& \\
7^{\text {th }}\end{array}$ & $\begin{array}{l}7^{\text {th }} \& \\
\text { 8th }\end{array}$ & $\begin{array}{c}8^{\text {th }} \& \\
9^{\text {th }}\end{array}$ & $\begin{array}{l}9^{\text {th } ~ \& ~} \\
\text { 10th }\end{array}$ & $\begin{array}{l}10^{\text {th } \&} \\
11 \text { th }\end{array}$ & $\begin{array}{l}1^{\text {1th } \&} \\
12^{\text {th }}\end{array}$ & Average \\
\hline CRTT-1 & 25 & 26 & 21 & 24 & 22 & 27 & 26 & 23 & 27 & 24 & 25 & 24.55 \\
\hline $\begin{array}{l}\text { CRTT-2 } \\
\end{array}$ & 27 & 27 & 21 & 24 & 23 & 25 & 27 & 22 & 26 & 21 & 26 & 24.45 \\
\hline CRTT-3 & 25 & 23 & 27 & 26 & 25 & 25 & 23 & 27 & 24 & 24 & 23 & 24.73 \\
\hline CRTT-4 & 21 & 23 & 27 & 26 & 24 & 25 & 23 & 24 & 26 & 24 & 22 & 24.09 \\
\hline CRTT-5 & 24 & 25 & 27 & 26 & 25 & 22 & 23 & 25 & 24 & 25 & 24 & 24.55 \\
\hline CRTT-6 & 22 & 24 & 26 & 27 & 26 & 25 & 26 & 25 & 23 & 24 & 23 & 24.64 \\
\hline Average & 24.00 & 24.67 & 24.83 & 25.50 & 24.17 & 24.83 & 24.67 & 24.33 & 25.00 & 23.67 & 23.83 & 24.50 \\
\hline
\end{tabular}

Table 2 shows the transfusion intervals of 41-48 days (Average 45 days) in the study group and Table 3 shows the transfusion intervals of 21-27 days (Average 24.5 days) in the control group. Moreover during the study period, it was observed that there were decreases of transfusion reactions in the study group. Figure 2 shows average transfusion intervals in days in transfusion of study group and control group.

\section{DISCUSSION}

We have seen in the study that there is $41.67 \%$ decrease of numbers of transfusion requirement in the study group than control group. At the same time, there is increase of transfusion intervals in the study group than control group. This is because neocytes concentrate units having half-life approximately twice than that of a conventional packed red blood cells units. As the transfusion intervals increased and numbers of transfusion ( 7 versus 12) decreased in study group than control group, so the observation is in accordance with previous study like Bertholey F et al 1990[17], Montoya AF et al 1993[18], Spanos T et al 1996[19] and Collin A F et al 1994.[21] Extension of transfusion intervals observed in our study group patients was significant i.e. 41-48 days (average 45 days) over control group patients, in which it was 21-27 days (average
24.5 days). It is nearly the same as observed by Propper et al 1980[16] and Collin A F et al 1994[21], 43 +/- 4.5 days and 3544.5 days respectively in their studies of neocytes transfusion.

Due to less exposure of red blood cells transfusion, there will be decreased chances of transfusion related hazards like transfusion reactions and transfusion transmitted infections.[23] Leuco-reduction helps in preventing most of the febrile reactions. Leuco-reduction of the units should be done in chronically transfused patients. We were unable to use leuco-depleted red blood cells (Irradiated RBCs) due to limited facilities in our centre.

Most of the pathological changes in beta-thalassemia major patients are thought to be secondary to both iron overload and chronic anaemia.[13,14] The prime source of iron deposition in the beta-thalassemia major patient is the transfused red blood cells. We know that each unit of conventional packed red blood cells transfusion adds about 200-250 mg of iron extra to the recipients. ${ }^{[1,2,4]}$ As in the study, numbers of neocytes concentrates/pooled neocytes transfused to the study group patients are quite lesser than the numbers of conventional packed red blood cells transfused to the control group patients, so serum iron reduction observed in the neocytes concentrate/pooled neocytes transfusion 
cases than conventional packed red blood cells transfused cases. The serum iron reduction was observed 5/12 X 100\% $=41.67 \%$ in study group in comparison to control group. Study done by Collin AF et al 1994[21] have observed reduction of serum ferritin level by $19.05 \%$. Prolongation of the life span of transfused young red blood cells, i.e. neocytes will result in decreased iron deposition per unit time. Hence, in the study group there will be prevention of iron overload and its sequel: growth failure, hypogonadism, diabetes mellitus, hepatic disease, cardiac failure and death. Serum iron reduction reduces iron overload on the study cases as iron overload is directly proportional to serum ferritin level.

In our study, we used super-transfusion regimen to maintain normal physiological level of haematocrit/haemoglobin in transfusion dependent betathalassemia major patients, which leads to better tissue oxygenation, reduction of blood volume, reduced intestinal absorption of iron by reducing plasma iron turnover[25] and benefit on bone development by reducing in the rate of ineffective erythropoiesis. [26]

Neocytes aphaeresis from a single donor reduces chances of exposure to multiple donors for haematological patients dependent on red blood cells transfusion. Though it is better than pooled neocytes concentrate preparation by centrifugation and separation method as it requires multiple donors still is also effective.

\section{CONCLUSION}

Transfusion of neocytes concentrate/pooled neocytes to maintain haematocrit $\geq 35 \%$ and haemoglobin level $\geq 11$ $\mathrm{gm} / \mathrm{dL}$ by super-transfusion regimen along with effective chelating therapy leads beta-thalassemia major patients better quality of life expectancy than conventional packed red blood cells transfusion correcting anaemia, extending transfusion intervals, reducing required numbers of red blood cells transfusion, increasing survival of transfused neocytes in vivo, helping in normal growth and bone development by suppressing ineffective erythropoiesis, decreasing chances of transfusion related hazards, reducing plasma iron turnover, protect vital organs and related complications reducing iron overload. At the end of the study the author opines that we should prefer transfusion of neocytes concentrate/pooled neocytes in beta-thalassemia major patients instead of conventional packed red blood cells transfusion. Moreover, where neocytes-aphaeresis facility is not available, there centrifugation and separation method for preparing neocytes is effective.

\section{ACKNOWLEDGEMENTS}

The author is thankful to the faculties of Paediatrics and Pathology Department and Laboratory Technicians of Blood Bank of Gauhati Medical College and Hospital, Guwahati for their close cooperation and help without which this study would have not been possible.

\section{REFERENCES}

1. John NL. The thalassemias and related disorders: quantitative disorders of hemoglobin synthesis. In: Lee GR, Foerster J, Lukens J, et al. (eds). Wintrobe's clinical hematology. 10th ed. Vol. 1. Baltimore: Lippincott Williams \& Wilkins 1999:1405-48.
2. Wild BJ, Bain BJ. Investigation of abnormal hemoglobin. In: Lewis SM, Bain BJ, Bates I, eds. Practical hematology. $9^{\text {th }}$ ed. London: Churchill Livingstone, Harcourt Publishers Limited 2001:235-7.

3. De Gruchy GC. Disorder of hemoglobin structure and synthesis. In: Penington D, Rush B, Castaladi P, eds. Clinical haematology in medical practice. $4^{\text {th }}$ ed. Delhi: CBS Publication and Distributors 1986:302-20.

4. Thalasemias. In: Kaspar DL, Fauci E, Hauser AS, et al. (eds). Harrison's Principles of Internal Medicine. $16^{\text {th }}$ ed. New York: McGraw Hill Company 2005:598-600.

5. Seth T. Hematological disorders. In: Ghai OP, Paul VK, Bagga A, eds. Textbook of pediatric. New Delhi: CBS Publication \& Distributors Pvt Limited 2009:307-10.

6. Allam NC, Ludlen CA. Diseases of blood. In: Edward CRW, Bouchier IAD, eds. Davidson's Principle and Practice of Medicine. 16 th ed. ELBS Publication 2001:721-23.

7. Cazzola M, Stefeno PD, Ponchio L, et al. Relationship between transfusion regimen and suppression of erythropoiesis in $\beta$-thalassemia major. British J Hematology 1995;89(3):473-8.

8. Cavill I, Rickets C, Jacobs A, et al. Erythropoiesis and the effect of transfusion in homozygous $\beta$-thalassemia. N Engl J Med 1978;298(14):776-8.

9. Thuret I. Therapeutic management of patients with thalassemia major. Bull Soc Pathol Exot 2001;94(2):95-7.

10. Weiner M, Kartpatkin M, Hart D, et al. Cooley's anemia: high transfusion regimen and chelation therapy results and perspective. J Pediatr 1978;92(4):653-8.

11. Masera G, Terzoli S, Avanzini A, et al. Evaluation of the super-transfusion regimen in homozygous beta thalassemia children. Br J Haematol 1982;52(1):111-3.

12. Iboral L. Transfusion Medicine. In: Henry BJ, ed. Clinical diagnosis and management by laboratory methods. $12^{\text {th }}$ ed. Philadelphia: WB Saunders Company 2001:738-9.

13. Hollan SR. Transfusion associated iron overload. Curr Opin Hematol 1997;4(6):436-41.

14. Proter JB. Practical management of iron overload. Curr Opin Hematol 1997;4:436-41.

15. Graziano JH, Markenson A, Miller DR, et al. Chelation therapy in $\beta$-thalassemia major. Intravenous and subcutaneous desferoxime. J Paediatr 1978;92(4):64852.

16. Propper RD, Button LN, Nathan DG. New approaches to the transfusion management of thalassemia. Blood 1980;55(1):55-60.

17. Bertholey F, Saint-Paul E, Chataing B, et al. Transfusion of concentrates enriched in neocytes in thalassemic child, preliminary results. Rev Fr Transfusion Hemobiol 1990;33(3):165-74.

18. Montoya AF. Neocyte transfusion: a current perspective. Transfusion Sciences 1993;14(2):147-56.

19. Spanos T, Ladis V, Palamidou F, et al. The impact of neocyte transfusion in the management of thalassemia. Vox Sang 1996;70(4):217-23.

20. Klein HG. Transfusion with young erythrocytes (neocytes) in sickle cell anemia. Am J Pediatr Hematol Oncol 1982;4(2):162-5.

21. Collins AF, Goncalves-Dias C, Haddad S, et al. Comparison of a transfusion preparation of newly formed red cells and standard washed red cell transfusion in patients with homozygous beta thalassemia. Transfusion 1994;34(6): 517-20. 
22. Kalinin NN, Varlamora SV, Pashinin AN, et al. Neocytapheresis in donors. Sov Med 1991;5:41-3.

23. Harmening DM. Modern blood banking and transfusion practices. $3^{\text {rd }}$ ed. Philadelphia: FA Davis 1990:342-3.

24. Technical manual. In: Vengelen-Tyler, ed. American Association of Blood Banks. 12th ed. Bethesda MD, 1996.
25. Wintrobe LR, Conrad ME, Crosby WH. Regulation of intestinal absorption of iron by the rate of erythropoiesis. Br J Haematol 1965;11:432-8.

26. Piomelli S, Danoff SJ, Becker MH, et al. Prevention of bone malformations and cardiomegaly in Colley's anemia by early hyper transfusion regimen. Ann N Y Acad Sci 1969;165(1):427-36. 